\title{
Physiological Research on the Difference of Bentazon Tolerance in Wild Type Rice and Sensitive Lethal Mutants
}

\author{
WANG Yun-Sheng ${ }^{1,2}$, LU Xu-Zhong ${ }^{2}$, SUN Ming-Na ${ }^{3}$, SONG Feng-Shun ${ }^{2}$, LI Li ${ }^{2}$, GAO Tong-Chun ${ }^{3}$, \\ and YANG Jian-Bo ${ }^{2, *}$ \\ $\left({ }^{1}\right.$ College of Biology Science, Anhui Agricultural University, Hefei 230036, Anhui; ${ }^{2}$ Rice Research Institute, Anhui Academy of Agricultural Sci- \\ ences, Hefei 230031, Anhui; ${ }^{3}$ Plant Protection Research Institute, Anhui Academy of Agricultural Sciences, Hefei 230031, Anhui, China)
}

\begin{abstract}
Bentazon sensitive lethal ( $b s l)$ mutants can be applied in hybrid rice (Oryza sativa L.) breeding for improving seed production and quality. This study was to elucidate the physiological mechanism of bentazon tolerance in rice. Tolerant rice varieties (W6154s and Norin 8) as well as their corresponding mutants, sensitive to bentazon, were employed in this study. Plant net photosynthetic rate $\left(P_{n}\right)$, chlorophyll fluorescence, and the level of superoxide radical $\left(\mathrm{O}_{2}^{\overline{2}}\right)$ as well as the contents of chlorophyll (Chl) and malondialdehyde (MDA), were analyzed for both tolerant and sensitive rice plants treated with bentazon. After treatment, the two sensitive mutants showed a significant reduction in $P_{\mathrm{n}}$ at $0.5 \mathrm{~h}$. A continuous decrease of Chl contents was found over the first $3 \mathrm{~d}$ whereas a significant increase of MDA contents was noticed on the 3rd day and thereafter. Analysis of chlorophyll fluorescence revealed a bentazon-induced increase in the proportion of the reduced state of $\mathrm{Q}_{\mathrm{A}}$. In the early stage after bentazon treatment, wild types and their mutants showed no significant difference in the alteration of $P_{\mathrm{n}}$ and chlorophyll fluorescence. While these two parameters then increased progressively in both wild types and remained low in the mutants. A significant generation of $\mathrm{O}_{\dot{2}}^{-}$was found over the $5 \mathrm{~d}$ period in the mutants. Both wild types and mutants contained the same level of bentazon after $2 \mathrm{~h}$ of treatment. Bentazon content dropped to barely detectable amount in the wild type varieties at $1 \mathrm{~d}$. However, the mutants retained a substantial amount of the herbicide after $5 \mathrm{~d}$. It is proposed that the herbicide might inhibit rice photophythesis and accumulation of oxidative stress with the treatment of bentazon in both lethal mutants. The damaging effect on PS II system can be significantly alleviated in the wild type varieties due to a higher rate of catabolism of the herbicide.
\end{abstract}

Keywords: Oryza sativa; Bentazon; Sensitive lethal mutant; Tolerance; Physiological research

\section{水稻及其敏感突变体苯达松抗性的生理生化差异研究}

王云生 $^{1,2}$ 陆徐忠 ${ }^{2}$ 孙明娜 ${ }^{3}$ 宋丰顺 ${ }^{2}$ 李 莉 ${ }^{2}$ 高同春 ${ }^{3}$ 杨剑波 ${ }^{2, *}$

$\left({ }^{1}\right.$ 安徽农业大学生命科学学院, 安徽合肥 $230036 ;^{2}$ 安徽省农业科学院水稻研究所, 安徽合肥 $230031 ;^{3}$ 安徽省农业科学院植物保护 研究所, 安徽合肥 230031)

摘 要: 苯达松敏感致死(bentazon sensitive lethal, $b s l$ )基因在杂交水稻(Oryza sativa L.)混播制种和杂交稻种纯度鉴定 等方面具有广阔的应用前景。以水稻品种农林 8 号(N8)、W6154s 和其对应的 $b s l$ 突变体农林 8 号 $\mathrm{m}(\mathrm{N} 8 \mathrm{~m})$ 和 $8077 \mathrm{~s}$ 为材料, 分析了苯达松处理对叶片中叶绿素 $(\mathrm{Chl})$ 含量、丙二醛 $(\mathrm{MDA})$ 含量、氧自由基含量、净光合速率 $\left(P_{\mathrm{n}}\right) 、$ 叶绿素 苂光参数等生理生化指标的影响及苯达松含量的变化, 旨在揭示水稻苯达松抗性差异的生理机制。结果表明, 苯达松 处理使 $b s l$ 突变体叶片光系统 II 中还原性 $\mathrm{Q}_{\mathrm{A}}$ 组分积累, 光合电子传递受阻, 光合能力丧失, 氧自由基伤害积累, Chl 降解、质膜氧化加剧, 植株死亡。叶片中苯达松残留含量分析表明, 较强的苯达松代谢能力是抗性品种免受苯达松伤 害的主要原因。

关键词: 水稻; 苯达松; 敏感致死突变体; 抗性; 生理

Hybrid rice technology is feasible and readily successful for raising rice yield potential. However, hybrid rice production is very labor intensive because the false hybrid seeds (self-pollination of sterile lines)

Foundation items: The Anhui Provincial Key Science and Technology Project of China (06003010B); the Nature Science Foundation of Anhui Provincial Education Department, China (2005KJ169)

Biography: WANG Yun-Sheng (1977-), male, PhD candidate, major research projects: crop genetic breeding and plant physiology. *Corresponding author: YANG Jian-Bo. Tel: +86 (0)551-2160212; E-mail: yjianbo@263.net

Received(收稿日期): 2008-01-04; Accepted(接受日期): 2008-03-26. 
have to be identified and removed, usually by hand. Chemical, morphological, and genetic markers have been investigated to identify the purity of rice hybrid seeds, even at the seedling stage ${ }^{[1-3]}$.

Bentazon [3-isopropyl-1H-2,1,3-benzothiadiazine$4(3 \mathrm{H})$-one 2,2-dioxide], known as basagran commercially, is used as a post-emergence herbicide with high selectivity for killing broadleaf weed. In general, common rice varieties (wild types) are all tolerant to bentazon, and can survive under foliar spray of $0.5 \%$ bentazon solution during the whole life cycle ${ }^{[3-4]}$. Norin $8 \mathrm{~m}(\mathrm{~N} 8 \mathrm{~m})$ is a bentazon sensitive lethal $(b s l)$ mutant, obtained by $\gamma$-ray radiation from a japonica rice, Norin $8(\mathrm{~N} 8)^{[5]}$. The $8077 \mathrm{~s}$ is also a $\gamma$-ray induced mutant from an indica photoperiod-temperature sensitive genic male sterile (P/TGMS) line, W6154s $\mathrm{s}^{[4,6]}$. Previous genetic studies on the cross-pollinated and self-pollinated progenies of the two mutants have confirmed that the $b s l$ phenotype of $\mathrm{N} 8 \mathrm{~m}$ or $8077 \mathrm{~s}$ is controlled by a single recessive gene ${ }^{[4-6]}$.

In hybrid breeding system, tagging the $b s l$ gene to the male sterile line can ensure the hybrid seeds free of false hybrids (self-pollination of sterile lines) by spraying bentazon at the seedling stage. On the other hand, if the $b s l$ gene is transferred into a restorer line, the restorer line is easily killed by spraying bentazon immediately after pollination, while the sterile line maintains normal growth and development. Therefore, the $b s l$ gene can be used an reasonable selective chemical marker in hybrid rice production so as to reduce labor $\operatorname{cost} t^{[4,6]}$.

Many researches have been performed to find molecular markers that are linked with the $b s l$ gene, and to provide an effective and powerful tool for marker-assisted selection for breeding purposes, in addition to the efforts to tag $b s l$ gene in map-based cloning $^{[6-7]}$. The results of map-based gene cloning showed that these mutants were caused by the mutation of the gene CYP81A6 encoding cytochrome P450 monooxygenases ${ }^{[8]}$. However, there is little information about physiological basis of bentazon resistance or sensitivity in wild type and bentazon-lethal mutants. The objectives of this study were to clarify physiological mechanisms of different responds to bentazon treatment between the wild type and their mutants. The results provided sufficient evidence for further $b s l$ gene isolation and characterization as well as its application in rice breeding.

\section{Materials and methods}

\subsection{Plant materials}

Seeds of N8m and its wild type N8 were kindly provided by Dr. Taketa from Japan. Seeds of mutant 8077 s and its wild type W6154s were obtained from
Dr. Ji-Wen Zhang, Hubei Academy of Agricultural Sciences, China. Surface-sterilized rice seeds were placed on moistened filter paper in a germination dish and incubated at $(28 \pm 2)^{\circ} \mathrm{C}$ for one week. Seedlings were transplanted into plastic trays $(80 \mathrm{~cm} \times 40 \mathrm{~cm} \times$ $10 \mathrm{~cm}$ ) filled with sandy loam soil. Plants (40 per tray) were grown under an irradiance of $800 \mu \mathrm{mol} \mathrm{m} \mathrm{m}^{-2} \mathrm{~s}^{-1}$ photosynthetically active radiation (PAR) from growth lamps (400-700 nm) and a 10/14 h (light/dark) photoperiod. Temperature in the greenhouse was maintained at $(30 \pm 2)^{\circ} \mathrm{C} /(20 \pm 2)^{\circ} \mathrm{C}$ (light/dark). At six-leaf stage, a thin layer of an aqueous solution containing $400 \mathrm{mg}$ $\mathrm{L}^{-1}$ bentazon (Sigma Co., USA) and $0.25 \%(\mathrm{~V} / \mathrm{V})$ Tween 20 was daubed on the surface of the fourth leaf with a fur brush. Distilled water containing $0.25 \%$ $(V / V)$ Tween 20 was daubed as control.

\subsection{Determination of chlorophyll and malondi- aldehyde contents}

Changes in chlorophyll (Chl) and malondialdehyde (MDA) contents were used as the indices of leaf injury by bentazon. The two indices were evaluated at $0,1,2,3,4$, and $5 \mathrm{~d}$ after treatment. For Chl extraction, approximately $0.5 \mathrm{~g}$ fresh leaves were homogenized in $10 \mathrm{~mL}$ of $80 \%$ acetone and followed by centrifugation at $5000 \times g$ for $5 \mathrm{~min}$. The supernatant was measured for absorbance at 663 and $645 \mathrm{~nm}^{[9]}$. To extract MDA, $0.5 \mathrm{~g}$ fresh leaves were homogenized in $10 \mathrm{~mL}$ of $5 \%$ $(W / V)$ trichloroacetic acid (TCA) and the mixture was centrifuged at $4000 \times g$ for $10 \mathrm{~min}$ at $4^{\circ} \mathrm{C}$. The MDA content was determined by measuring the absorbance at 532 and $600 \mathrm{~nm}^{[10]}$.

\subsection{Determination of superoxide radical}

$0.5 \mathrm{~g}$ frozen leaf segments were homogenized with $5 \mathrm{~mL}$ of $65 \mathrm{mmol} \mathrm{L}^{-1}$ potassium phosphate buffer (pH 7.8) and centrifuged at $5000 \times g$ for $10 \mathrm{~min}$. $\mathrm{O}_{2}^{-}$ was measured as described by monitoring the nitrite formation from hydroxylamine in the presence of $\mathrm{O}_{2}^{-[11]}$ A standard curve with $\mathrm{NO}_{2}^{-}$was used to calculate the production rate of $\mathrm{O}_{2}^{-}$from the chemical reaction of $\mathrm{O}_{2}^{-}$and hydroxylamine.

\subsection{Measurements of photosynthesis and re- lated parameters}

Leaf net photosynthetic rate $\left(P_{n}\right)$ was measured using a portable photosynthesis system (Model CI-310, CID Inc., USA) operating in the semi-open mode. External air was scrubbed of $\mathrm{CO}_{2}$ and mixed with a supply of pure $\mathrm{CO}_{2}$ to result in a reference $\mathrm{CO}_{2}$ concentration of $350 \mu \mathrm{L} \mathrm{L}^{-1}$.

Chlorophyll fluorescence was measured using a portable fluorometer (PAM 2100, Walz, Effeltrich, Germany). Steady-state fluorescence during diurnal illumination was measured using a leaf clip (Model 2030-B, Walz). Dark adaptation of leaves also took place with the leaf clips (Walz) for $20 \mathrm{~min}$ before 
measurements. The maximum amount of fluorescence $\left(F_{\mathrm{m}}\right)$ was recorded with a saturating flash of light, while the minimal amount of fluorescence $\left(F_{\mathrm{o}}\right)$ was recorded in the dark. The ratio of variable fluorescence $\left(F_{\mathrm{v}}\right)$ to $F_{\mathrm{m}}\left(F_{\mathrm{v}} / F_{\mathrm{m}}\right)$ was calculated by $F_{\mathrm{v}} / F_{\mathrm{m}}=\left(F_{\mathrm{m}}-\right.$ $\left.F_{\mathrm{o}}\right) / F_{\mathrm{m}}$. Fluorescence yield $\left(\Phi_{\mathrm{PSII}}\right)$ was calculated by $\Phi_{\text {PSII }}=\left(F_{\mathrm{m}}{ }^{\prime}-F_{\mathrm{v}}\right) / F_{\mathrm{m}}{ }^{\prime}$, where $F_{\mathrm{m}}{ }^{\prime}$ was detected from the leaf sample after application of a saturating light pulse of high quantum flux density $\left(5000 \mu \mathrm{mol} \mathrm{m} \mathrm{m}^{-2} \mathrm{~s}^{-1}\right)$, and $F$ was the fluorescence intensity in the steady state of photosynthesis. Photochemical quenching coefficient $\left(q_{\mathrm{p}}\right)$ was calculated by $q_{\mathrm{p}}=\left(F_{\mathrm{m}}{ }^{\prime}-F_{\mathrm{v}}\right) /\left(F_{\mathrm{m}}{ }^{\prime}-F_{\mathrm{o}}{ }^{\prime}\right){ }^{[12]}$

\subsection{Extraction and quantification of bentazon}

High performance liquid chromatography (HPLC) was performed to determine Bentazon content in treated leaves $^{[13]}$. Fresh leaves were sampled once every $2 \mathrm{~h}$ after application of bentazon solution. The leaf tissue $(5 \mathrm{~g})$ was homogenized in $80 \mathrm{~mL}$ of methanol. After filtering the mixture through the filter paper, the volume of the extraction solution was reduced to $5 \mathrm{~mL}$ in a speed vaccum concentrator. The concentrated sample was dissolved in $80 \mathrm{~mL}$ of ethanamide and extracted twice with $30 \mathrm{~mL}$ of ethane. A standard calibration was prepared using the pure bentazon (Sigma Co. USA).

\subsection{Statistical analyses}

Statistical differences among genotypes and different time periods of bentazon treatment were analyzed following the Student's $t$-test with SPSS software (Chicago, IL, USA). Differences were considered to be significant at $P<0.05$ probability level.

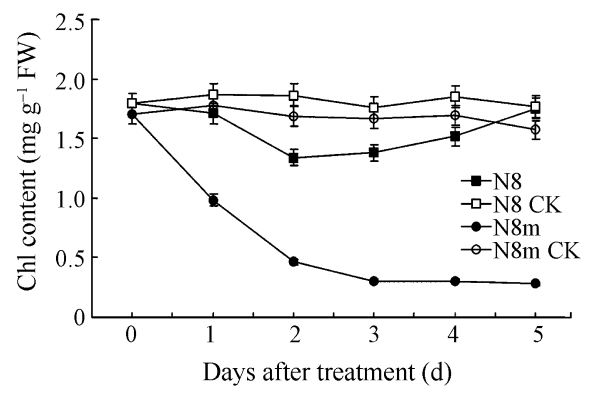

\section{Results}

\subsection{Injury indices of bentazon}

$\mathrm{N} 8$ and its mutant N8m had lower chlorophyll contents $\left[(1.81 \pm 0.15)\right.$ and $(1.73 \pm 0.17) \mathrm{mg} \mathrm{g}^{-1} \mathrm{FW}$, mean $\pm S E]$ than W6154s $\left[(2.095 \pm 0.04) \mathrm{mg} \mathrm{g}^{-1} \mathrm{FW}\right]$ and its corresponding mutant $8077 \mathrm{~s}[(2.04 \pm 0.15) \mathrm{mg}$ $\mathrm{g}^{-1} \mathrm{FW}$. After bentazon treatment, leaf $\mathrm{Chl}$ contents in both wild type varieties decreased over the first $2 \mathrm{~d}$, and then increased gradually, which was similar to those of untreated controls at $5 \mathrm{~d}$ after bentazon treatment (Fig. 1). In contrast, Chl contents in the two mutants decreased continuously during the 5-d period of observation, and N8m was more affected than $8077 \mathrm{~s}$. On the fifth day after treatment, Chl contents in N8m and $8077 \mathrm{~s}$ were $16.09 \%$ and $39.61 \%$ of their corresponding wild type varieties. MDA content highly increased starting at $3 \mathrm{~d}$ in both mutants, while it remained relatively low in the wild types during the whole period of treatment (Fig. 2).

\subsection{Superoxide radical}

Level of $\mathrm{O}_{2}^{-}$in leaves of the wild types increased rapidly at $1 \mathrm{~d}$ after bentazon treatment, followed by an continuous decrease and approached control level at $3 \mathrm{~d}$ (Fig. 3). The level of $\mathrm{O}_{2}^{-}$in the two mutants increased quickly and could not recover over the $5 \mathrm{~d}$ period. On the fifth day after treatment, the parameter in $\mathrm{N} 8 \mathrm{~m}$ and $8077 \mathrm{~s}$ was increased by $89.06 \%$ and $74.33 \%$ compared with those in their corresponding wild type varieties, respectively.

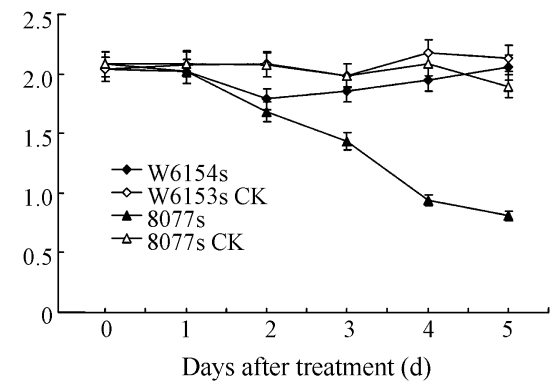

Fig. 1 Effect of bentazon $\left(400 \mathrm{mg} \mathrm{L}^{-1}\right)$ on the chlorophyll (chl) content in control and treated leaves of different rice varieties CK means treatment with distilled water containing $0.25 \%(V / V)$ of Tween 20. Each value is the mean of three replicates and is representative of three independent experiments. The vertical and horizontal bars indicate standard errors of means.
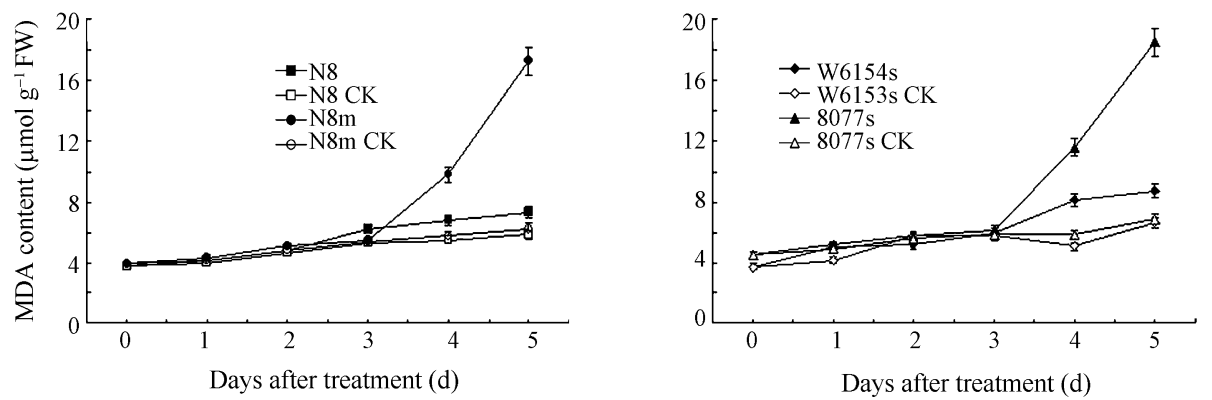

Fig. 2 Effect of bentazon (400 $\mathrm{mg} \mathrm{L}^{-1}$ ) on the malondialdehyde (MDA) content in control and treated leaves of different rice varieties CK means treatment with distilled water containing $0.25 \%(V / V)$ of Tween 20 . Each value is the mean of three replicates and is representative of three independent experiments. The vertical and horizontal bars indicate standard errors of means. 

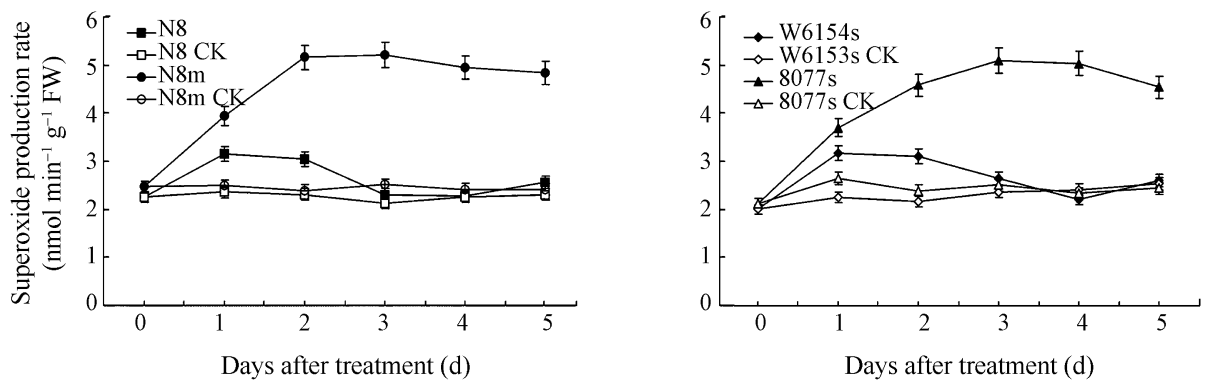

Fig. 3 Effect of bentazon $\left(400 \mathrm{mg} \mathrm{L}^{-1}\right)$ on the level of $\mathrm{O}_{2}^{-}$in control and treated leaves of different rice varieties

CK means treatment with distilled water containing $0.25 \%(V / V)$ of Tween 20. Each value is the mean of three replicates and is representative of three independent experiments. The vertical and horizontal bars indicate standard errors of means.

\subsection{Photosynthesis}

The average $P_{\mathrm{n}}$ of control leaves was significantly lower in $\mathrm{N} 8$ and its mutant $\mathrm{N} 8 \mathrm{~m}[(17.31 \pm 0.74)$ and $(16.9 \pm 0.87) \mu \mathrm{mol} \mathrm{m} \mathrm{m}^{-2} \mathrm{~s}^{-1}$, mean $\left.\pm S E\right]$ than in W6154s and its mutant $8077 \mathrm{~s}[(20.52 \pm 1.19)$ and $\left.(18.68 \pm 1.11) \mu \mathrm{mol} \mathrm{m} \mathrm{m}^{-2} \mathrm{~s}^{-1}\right]$. The average $P_{\mathrm{n}}$ of the wild types decreased rapidly and became undetectable (zero) at approximately $0.5 \mathrm{~h}$ after bentazon treatment, followed by a continuous increase and approached control level at $1 \mathrm{~d}$ (Fig. 4). The two mutants could not recover from the bentazon damage and $P_{\mathrm{n}}$ remained near zero over the $5 \mathrm{~d}$ period. It was noted that after treatment, $P_{\mathrm{n}}$ of W6154s recovered more quickly than that of $\mathrm{N} 8$.

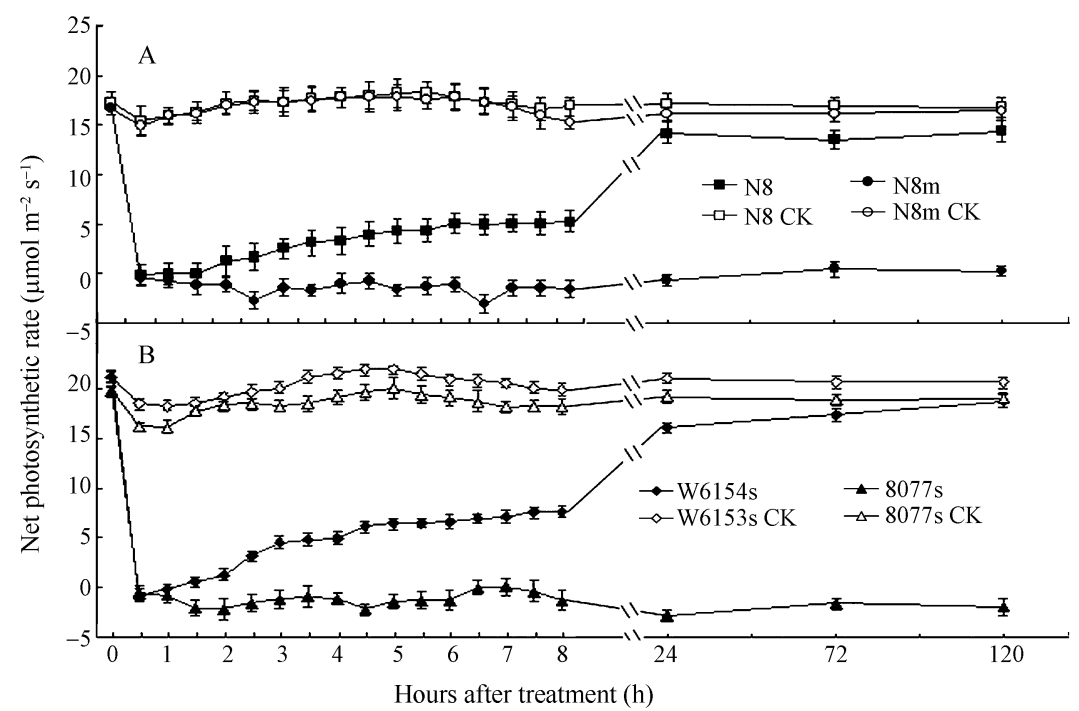

Fig. 4 Effect of bentazon $\left(400 \mathrm{mg} \mathrm{L}^{-1}\right)$ on the net photosynthetic rate $\left(P_{\mathrm{n}}\right)\left(\right.$ at $\left.1000 \mu \mathrm{mol} \mathrm{m}^{-2} \mathrm{~s}^{-1}\right)$ in control and treated leaves of different rice varieties

CK means treatment with distilled water containing $0.25 \%(V / V)$ of Tween 20. Each value is the mean of three replicates and is representative of three independent experiments. The vertical and horizontal bars indicate standard errors of means.

\subsection{Chlorophyll fluorescence}

Figure 5 presents the changes in the minimal fluorescence yield $\left(F_{\mathrm{o}}\right)$ and the maximal efficiency of PSII photochemistry $\left(F_{\mathrm{v}} / F_{\mathrm{m}}\right)$ in dark-adapted state in control and treated leaves. The average $F_{\mathrm{v}} / F_{\mathrm{m}}$ showed a significant reduction in the first $2 \mathrm{~h}$ after treatment. The mean value was $12.3 \%$ for $\mathrm{N} 8$ and $\mathrm{N} 8 \mathrm{~m}$, and $10.3 \%$ for W6154s and $8077 \mathrm{~s}$ (Fig. 5-B). After the initial reduction, the $F_{\mathrm{v}} / F_{\mathrm{m}}$ value increased gradually in the two wild type varieties. One day after treatment, the $\mathrm{N} 8$ had $92.5 \%$ of $F_{\mathrm{v}} / F_{\mathrm{m}}$ compared with control and W6154s recovered completely $(99.9 \%)$. For the two mutants, the $F_{\mathrm{v}} / F_{\mathrm{m}}$ decreased, and the average $F_{\mathrm{o}}$ in- creased continuously over the $5 \mathrm{~d}$ observation period (Fig. 5).

The above results indicate that bentazon treatment might have a significant impact on the primary photochemistry of PS II in dark-adapted leaves of both mutants. However, the leaves of the wild type varieties were able to recover from bentazon injury over time. We further investigated whether bentazon treatment could induce any significant changes in PS II photochemistry in light-adapted leaves at 2 and $24 \mathrm{~h}$ time period after treatment. In the control leaves without bentazon application, the two genotypes exhibited similar changes ( $\Phi_{\mathrm{PSII}}$ and $q_{\mathrm{p}}$ decrease) with increasing 

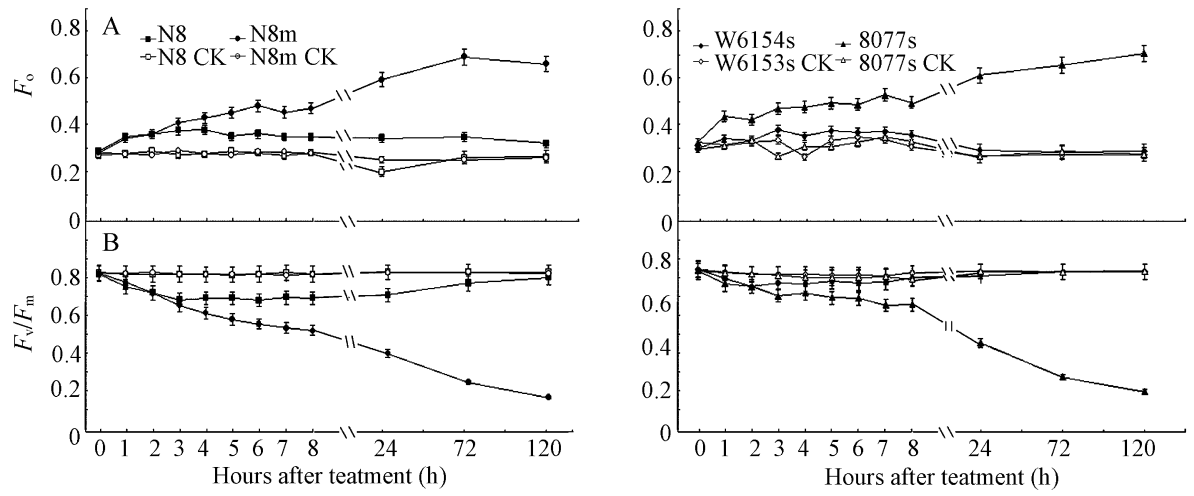

Fig. 5 Effect of bentazon $\left(400 \mathrm{mg} \mathrm{L}^{-1}\right)$ on the minimal fluorescence yield $\left(F_{0}\right)$ and the maximal efficiency of PS II photochemistry $\left(F_{\mathrm{v}} / F_{\mathrm{m}}\right)$ in dark-adapted state in control and treated leaves of different rice varieties

CK means treatment with distilled water containing $0.25 \%(V / V)$ of Tween 20 . Each value is the mean of three replicates and is representative of three independent experiments. The vertical and horizontal bars indicate standard errors of means.

PFD (Fig. 6 and Fig. 7). After bentazon application, the two parameters $\left(\Phi_{\mathrm{PSII}}\right.$ and $q_{\mathrm{p}}$ ) of the two wild type varieties and mutants decreased to zero at $2 \mathrm{~h}$ after bentazon treatment (Fig. 6). Differences between wild type varieties and mutants were observed at $24 \mathrm{~h}$ after treatment. In the wild type varieties, trend of changes in these two parameters was similar between treatment and the control. The only difference was that the absolute values were significantly lower in the treated leaves with a $\Phi_{\text {PSII }}$ of $46.0 \%$ for $\mathrm{N} 8$ and $20.1 \%$ for $\mathrm{W} 6154 \mathrm{~s}$. However, the parameters in the mutants remained much lower compared to the wild type varieties and the untreated control (Fig. 7).

\subsection{Absorption and catabolism of bentazon}

Bentazon content in plants increased very fast and reached its peak $\left[\mathrm{N} 8,(18.47 \pm 0.56) \mathrm{mg} \mathrm{g}^{-1} \mathrm{FW}\right.$; $\mathrm{N} 8 \mathrm{~m},(18.62 \pm 0.57) \mathrm{mg} \mathrm{g}^{-1} \mathrm{FW}$; W6154s, (19.41 \pm $0.15) \mathrm{mg} \mathrm{g}^{-1} \mathrm{FW} ; 8077 \mathrm{~s},(19.56 \pm 0.50) \mathrm{mg} \mathrm{g}^{-1} \mathrm{FW}$, mean $\pm S E$ ] within the first $2 \mathrm{~h}$ after treatment. Differences in reduction of leaf bentazon content among the wild type varieties and their mutants were presented in Fig. 8. One day after treatment, the content of bentazon dropped to $(5.58 \pm 0.32) \mathrm{mg} \mathrm{g}^{-1} \mathrm{FW}$ in $\mathrm{N} 8 \mathrm{~m}$ and $(6.28 \pm 0.31) \mathrm{mg} \mathrm{g}^{-1} \mathrm{FW}$ in $8077 \mathrm{~s}$, and remained at this level during the $5 \mathrm{~d}$ treatment period (data not presented). In the wild type varieties, bentazon contents decreased much more dramatically, and became barely detectable after $1 \mathrm{~d}$ of treatment. In addition, bentazon contents reduced faster in W6154s than in N8.
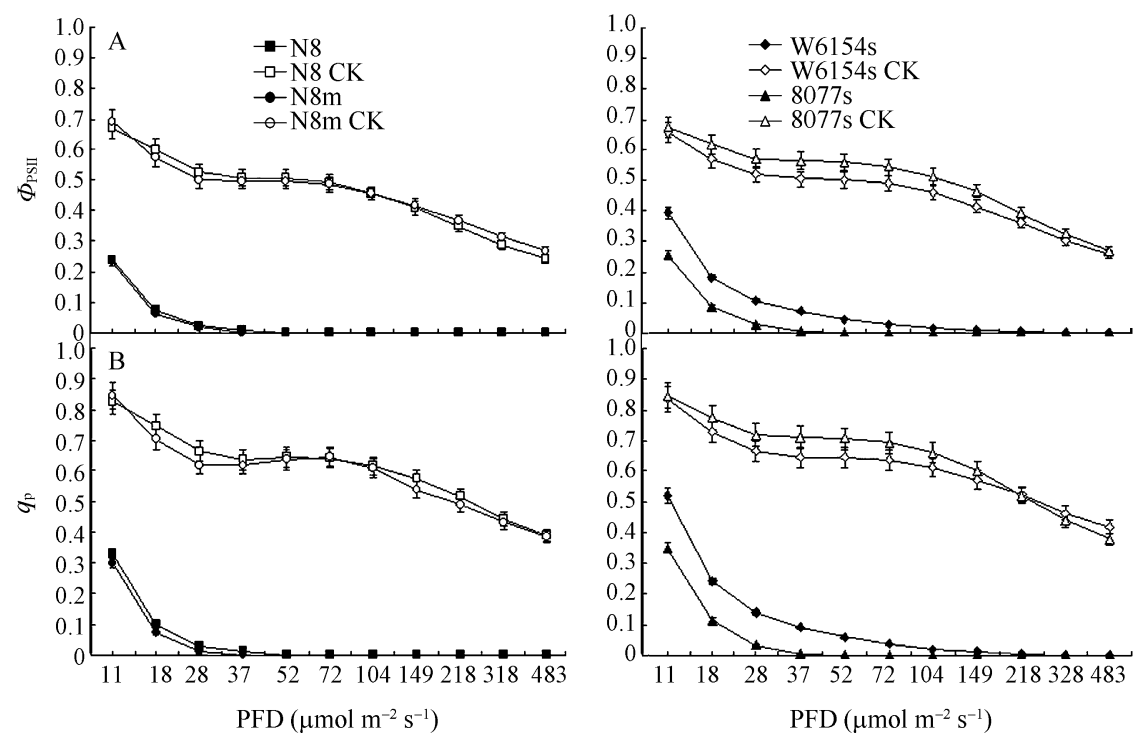

Fig. 6 The light response curves of actual quantum yield of PS II photochemistry ( $\Phi_{\mathrm{PSII}}$, A) and photochemical quenching ( $q_{\mathrm{p}}$, B) in control and treated leaves of different rice varieties at $2 \mathrm{~h}$ bentazon $\left(400 \mathrm{mg} \mathrm{L}^{-1}\right)$ treatment

CK means treatment with distilled water containing $0.25 \%(V / V)$ of Tween 20 . Each value is the mean of three replicates and is representative of three independent experiments. The vertical and horizontal bars indicate standard errors of means. 

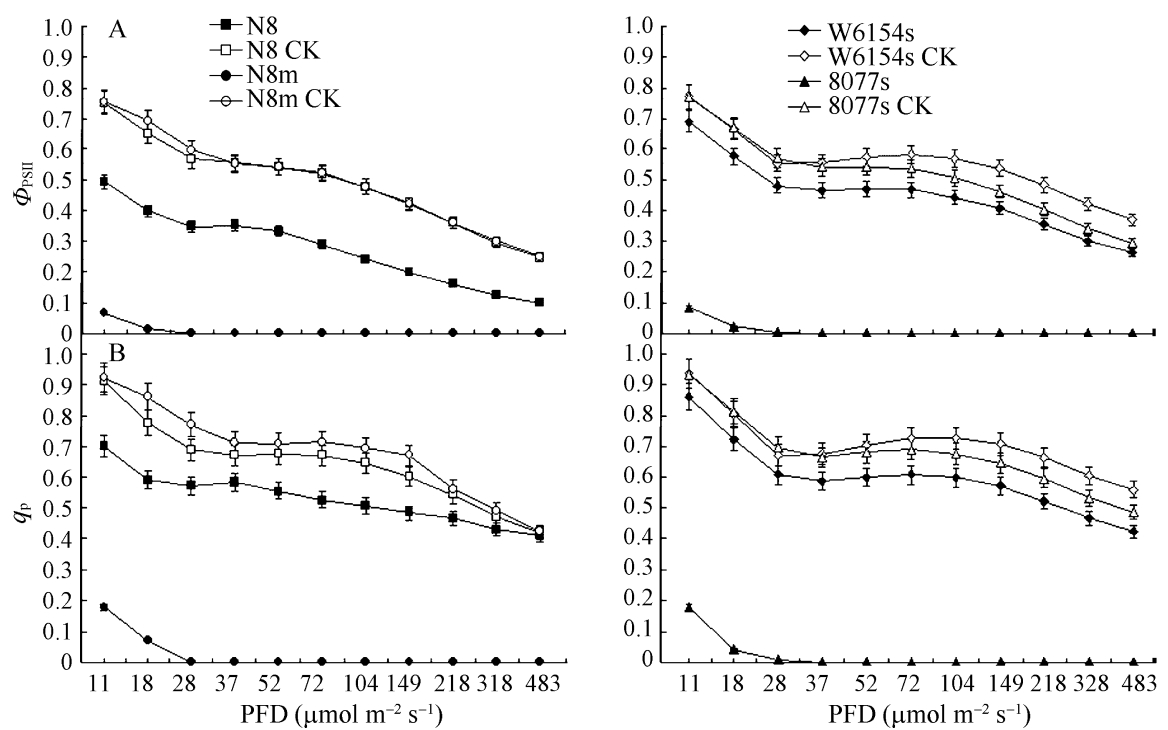

Fig. 7 The light response curves of actual quantum yield of PSII photochemistry ( $\left.\Phi_{\mathrm{PSII}}, \mathrm{A}\right)$ and photochemical quenching $\left(q_{\mathrm{p}}\right.$, B) in control and treated leaves of different rice varieties at $24 \mathrm{~h}$ bentazon $\left(400 \mathrm{mg} \mathrm{L}^{-1}\right)$ treatment

CK means treatment with distilled water containing $0.25 \%(V / V)$ of Tween 20 . Each value is the mean of three replicates and is representative of three independent experiments. The vertical and horizontal bars indicate standard errors of means.

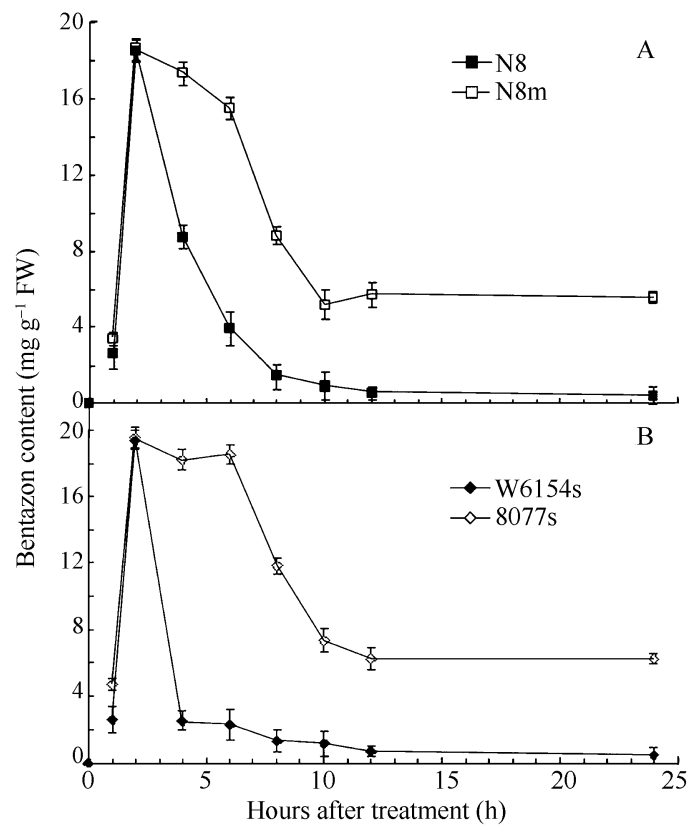

Fig. 8 Changes of bentazon content in treated leaves of different rice varieties in $24 \mathrm{~h}$ after bentazon $\left(400 \mathrm{mg} \mathrm{L}^{-1}\right)$ treatment Each value is the mean of three replicates and is representative of three independent experiments. The vertical and horizontal bars indicate standard errors of means

\section{Discussions}

Previous researches showed that the primary action of bentazon is to compete for the binding site in the $\mathrm{D}_{1}$ protein with plastoquinone $\left(\mathrm{Q}_{\mathrm{B}}\right)$ in the photosystem $\mathrm{II}^{[14-15]}$. The herbicide will be converted through the cytochrome P450 monooxygenase system into inactive metabolites once it enters the cells of tolerant plants ${ }^{[15-16]}$. Plant response to bentazon depends on absorption, catabolism, and the affinity of the herbicide with the target site of $\mathrm{D}_{1}$ protein in PS II. Therefore, changes in Chl contents, MDA contents, level of $\mathrm{O}_{\dot{2}}^{-}$, net photosynthetic rate, chlorophyll fluorescence, and bentazon content in treated leaves were compared using the two mutants and their wild types in this study.

\subsection{The mechanism of bentazon sensitivity in mutants}

Chlorophyll fluorescence provides information about the state of PS II. It is an estimate of the extent to which PS II is using the energy absorbed by chlorophyll and the extent to which it is being damaged by excess light. In this study, the changes in the chlorophyll fluorescence were monitored to explore the mechanism whereby the $P_{\mathrm{n}}$ was reduced in treated leaves of the mutants. The data showed that foliar application of bentazon induced an irreversible inhibition of photophythesis in both mutants. The inhibition, indicated by a sustained reduction in $F_{\mathrm{v}} / F_{\mathrm{m}}$ and an increased $F_{\mathrm{o}}$ (Fig. 5), is associated with a decline in the intrinsic quantum yield of $\mathrm{CO}_{2}$ assimilation. The dramatic and irreversible decrease in $q_{\mathrm{p}}$ and $\Phi_{\text {PSII }}$ at 2 and $24 \mathrm{~h}$ time period after bentazon treatment may indicate a significant increase in the proportion of the closed PS II reaction centers or in the proportion of the reduced state of $Q_{A}{ }^{[9,17]}$. Bentazon competitively binds to $\mathrm{D}_{1}$ protein and reduces the binding sites for $\mathrm{Q}_{B}$ thus causing blockage of the electron transfer from $\mathrm{Q}_{\mathrm{A}}$ to $\mathrm{Q}_{\mathrm{B}}{ }^{[18]}$. It could be suggested that the accumulation of the reduced state of $\mathrm{Q}_{\mathrm{A}}$ induce the loss of $P_{\mathrm{n}}$ in the bentazon treated leaves of both mutants. 
The increase in the fraction of $\mathrm{Q}_{\mathrm{A}}$ in the reduced state suggests an increase in the excitation pressure on PSII under the steady-state of photosynthesis, resulting in abundant generation of $\mathrm{O}_{2}^{-}$(Fig. 3). The abundant generation of $\mathrm{O}_{2}^{-}$can cause further photodamage on chloroplasts or cells if excessive excitation energy is not safely dissipated ${ }^{[19]}$. Changes in MDA and Chl contents indicate that the lethal effect of bentazon in both mutants is due to accumulation of oxidative stress, which in turn acts on chloroplasts and membrane system, causing Chl degredation and membrane lipid peroxidation $^{[20]}$.

\subsection{Bentazon resistant mechanism in the wild type}

When the values of $P_{\mathrm{n}}$ and the chlorophyll fluorescence were compared among the two wild type varieties and their mutants, no significant difference was observed within $2 \mathrm{~h}$ after bentazon treatment. As the fluorescence characteristics during the steady-state of photosynthesis are representative of the efficiency of electron transfer in PS II, the results indicate that the affinity of the target site $\left(\mathrm{D}_{1}\right.$ protein in $\mathrm{PS}$ II) to bentazon is roughly equal in the wild type varieties and their mutants. However $P_{\mathrm{n}}$ and chlorophyll fluorescence parameters increased progressively and approached the control for the wild types $1 \mathrm{~d}$ after treatment. Therefore, the inhibition was significantly alleviated during the process and very slight photodamage has been incurred in treated leaves of both original varieties.

Changes of Bentazon content were investigated to define the correlation between bentazon accumulation and the recovery efficiency of photosynthetic capacity after foliar application of the herbicide. This study reveals that wild type varieties absorbed bentazon as equally as the mutants during the first $2 \mathrm{~h}$, which is approved by similar content of bentazon in the leaf tissues. After $8 \mathrm{~h}$, bentazon was metabolized into other non-toxic molecules and became almost undetectable in the wild type plants, but substantial amount of the herbicide was retained in the leaf tissues of both mutants. Based on the correlation between catabolism of bentazon and changes in photosynthetic parameters, it is proposed that the reduction of bentazon is the essential reason for the recovery of photosynthetic capacity in the two wild type varieties.

In a previous study, it was found that $\mathrm{N} 8 \mathrm{~m}$ was more sensitive to bentazon than $8077 \mathrm{~s}^{[8]}$. The current research detected that the $\mathrm{Chl}$ content decreased faster in $\mathrm{N} 8 \mathrm{~m}$ than in $8077 \mathrm{~s}$ after exposure to bentazon (400 $\mathrm{mg} \mathrm{L}^{-1}$ ). When the two wild type varieties were compared, N8 was significantly slower and more delayed in the recovering rate of photosynthetic capacity and the metabolizing rate of bentazon than W6154s. No significant differences in MDA content, $P_{\mathrm{n}}$, chloro- phyll fluorescence and bentazon content were detected between the two mutants. Therefore it is indicated that bentazon sensitivity of the mutants could be affected by the physiological characteristics.

\section{Conclusions}

By analyzing parameters associated with photosynthetic efficiency and bentazon catabolism, and correlating them with the genotypes, we have identified the possible physiological mechanism for bentazon tolerance/sensitivity in rice wild types and their bsl mutants. It is proposed that the herbicide might inhibit rice photophythesis and accumulation of oxidative stress with the treatment of bentazon in both mutants. And a rapid catabolism of bentazon in the wild type is the essential mechanism for their tolerance.

Acknowledgement: The authors thank Dr. Hong-Jun Zheng for kindly providing the manuscript amendment.

\section{References}

[1] Dong F-G(董凤高), Zhu X-D(朱旭东), Xiong Z-M(熊振民), Cheng S-H(程式华), Sun Z-X(孙宗修), Min S-K(闵绍楷). Breeding of photo-thermoperiod sensitive genic male-sterile indica rice with a pale-green-leaf marker. Chin J Rice Sci (中国水 稻科学), 1995, 9(2): 65-70 (in Chinese with English abstract)

[2] Yashitola J, Thirumurugan T, Sundaram R M, Nasscerallah M K, Ramesha M S, Sarma N P, Sonti R V. Assessment of purity of rice hybrids using microsatellite and STS markers. Crop Sci, 2002, 42: 1369-1373

[3] Liang T-X(梁天锡), Lou X-H(楼小华). Studies on the residues and degradation behavior of herbicide resistant gene. Chin J Rice $S c i$ (中国水稻科学), 1990, 4(2): 84-88 (in Chinese with English abstract)

[4] Zhang J-W(张集文), Wu X-Z(武晓智). Screening and preliminary study on the chemical lethal mutant in rice photoperiod-temperature sensitive malesterile sensitive male sterile line. Chin J Rice Sci (中国水稻科学), 1999, 13(2): 65-68 (in Chinese with English abstract)

[5] Mori K. Inheritance of susceptible mutant in rice plant to herbicide bentazon. Jpn J Breed, 1984, 34(suppl-1): 421-422

[6] Zhang J, Xu Y, Wu X, Zhu L. A bentazon and sulfonylurea sensitive mutant: breeding, genetics and potential application in seed production of hybrid rice. Theor Appl Genet, 2002, 105: 16-22

[7] Xiang T, Yang J, Li L, Ni D, Yang Q, Zhu Q, Wang X, Zhang Y, Huang D. Development of RAPD markers and SCAR markers linked to bentazon susceptible lethality gene in rice. Acta Bot Sin, 2003, 45: 223-228

[8] Pan G, Zhang X, Liu K, Zhang J, Wu X, Zhu J, Tu J. Map-based cloning of a novel rice cytichrome P450 gene CYP81A6 that confers resistance to two different classes of herbicides. Plant 
Mol Biol, 2006, 61: 933-943

[9] Porra R J, Thompson W A, Kriedemann P E. Determination of accurate extinction coefficients and simultaneous equations for assaying chlorophyll a and b extracted with four different solvents: verification of the concentration of chlorophyll standards by atomic absorption spectroscopy. Biochim Biophys Acta, 1989, 975: 384-394

[10] Heath R L, Packer L. Photoperoxidation in isolated chloroplasts: I. Kinetics and stoichiometry of fatty acid peroxidation. Arch Biochem Biophys, 1968, 125: 189-198

[11] Elstner E F, Heupel A. Inhibition of nitrite formation from hydroxylammoniumchloride: a simple assay for superoxide dismutase. Anal Biochem, 1976, 70: 616-620

[12] Genty B, Briantais J M, Baker N R. The relationship between the quantum yield of photosynthetic electron transport and quenching of chlorophyll fluorescence. Biochim Biophys Acta, 1989, 990: 87-92

[13] Wang Y-S(王云生), Sun M-N(孙明娜), Lu X-Z(陆徐忠), Gao T-C(高同春), Yang J-B(杨剑波). HPLC determination of bentazon and its metabolites. Agrochemicals (农药), 2006, 45(2): 113-115 (in Chinese with English abstract)
[14] McFadden J J, Gronwald J W, Eberlein C V. In vitro hydroxylation of bentazon by microsomes from naphthalic anhydridetreated corn shoots. Biochem Biophys Res, 1990, 168: 206-213

[15] Burton J D, Maness E P. Constitutive and inducible bentazon hydroxylation in shattercane (Sorghum bicolor) and johnsongrass ( $S$ halapense). Pestic Biochem Physiol, 1992, 44: 40-49

[16] Gronwald J W, Connelly J A. Effect of monooxygenase inhibitors on bentazon uptake and metabolism in maize cell suspension cultures. Pestic Biochem Physiol, 1991, 40: 284-294

[17] Dietz K J, Schreiber U, Heber U. The relationship between the redox state of QA and photosynthesis in leaves at various carbon-dioxide, oxygen and light regimes. Planta, 1985, 166: 219-226

[18] Ahrens W H. Herbicide Handbook. 7th edn. Champaign IL: Weed Science Society of America Press, 1994. p 352

[19] Demming-Adams B, Adams III W W. Photoprotection and other responses of plants to high light stress. Ann Rev Plant Physiol Plant Mol Biol, 1992, 43: 599-626

[20] Shen B, Jensen R G, Bohnert H J. Increased resistance to oxidative stress in transgenic plants by targeting mannitol biosynthesis to chloroplast. Plant Physiol, 1997, 113: 1177-1183

\section{欢迎订阅 2009 年《植物保护》}

《植物保护》创刊于 1963 年, 由中国植物保护学会和中国农业科学院植物保护研究所主办, 为全国中 文核心期刊、中国科技核心期刊、“中国期刊方阵”双百期刊，曾荣获中国科协优秀科技期刊奖、全国优秀 科技期刊奖，北京市全优期刊奖、国家期刊奖提名奖等多个奖项。收录的数据库有英国 CABI 文献数据库、 联合国粮农组织 Agrindex (FAO)数据库、美国《化学文摘》(CA)、中国科学引文数据库、中文科技期刊数 据库、《生物学文摘》、万方数据一数字化期刊群、中国农业文摘数据库、中国科技论文与引文数据库、中 国学术期刊(光盘版)、中国期刊网。本刊主要刊登有关植物病理、农林业昆虫、杂草及鼠害等农作物有害生 物、植物检疫、农药等植物保护学科各领域原始研究性论文和具有创新性、实用性技术成果文章。设有专 论与综述、研究报告、调查研究、基础知识、实验技术、国外植保、争鸣、应用与交流、病虫新动态、学 会动态与信息、新书新产品介绍等栏目。

竭诚欢迎全国各地科研院所研究人员、大专院校教师及研究生、各级植保科技工作者等踊跃订阅。欢 迎广大作者踊跃投稿！并欢迎咨询洽谈广告业务！

本刊为双月刊，大 16 开，160页，铜版纸印刷。每期定价 25.00 元，全年 150.00 元。邮发代号：2-483， 全国各地邮局均可订阅。直接在本刊编辑部订阅，可享受 9 折优惠价，全年 135 元，若需挂号，每期另加 3 元。

地址：北京圆明园西路 2 号中国农科院植保所《植物保护》编辑部(邮编：100193)

电话：010-62819059，62815914；传真：010-62815914

E-mail: zwbh1963@263.net; 网址: http://www.plantprotection.ac.cn

联系人: 王音，高洪荣 